\title{
Clear Cell Neoplasm
}

National Cancer Institute

\section{Source}

National Cancer Institute. Clear Cell Neoplasm. NCI Thesaurus. Code C66752.

A purely morphologic term that describes a neoplasm in which all or the majority of the neoplastic cells have a clear cytoplasm, when examined under light microscopy, using the conventional staining method $(\mathrm{H}-\mathrm{E})$. This term does not provide any information about the nature of the neoplasm (benign or malignant), cell of orig in (e.g. epithelial versus mesenchymal versus hematopoietic), or prognosis. Further examination using special stains and/or immunohistochemistry is required to appropriately classify this tumor. 